\title{
DNA Methylation Changes Were Involved in Inhibiting Ethylene Signaling and Delaying Senescence of Tomato Fruit Under Low Temperature
}

\author{
Wenhui Duan \\ Hainan University \\ Shiyin Xie \\ Hainan University \\ Hongmiao Song ( $\square$ hmsongibcas@126.com ) \\ Hainan University https://orcid.org/0000-0002-0189-0071
}

\section{Research Article}

Keywords: DNA methylation, Ethylene signaling, Fruit senescence, Tomato

Posted Date: July 30th, 2021

DOI: https://doi.org/10.21203/rs.3.rs-706773/v1

License: (c) (i) This work is licensed under a Creative Commons Attribution 4.0 International License.

Read Full License 


\section{Abstract}

Objectives To comprehend the epigenetic mechanism of low temperature in delaying senescence of fruit, the changes of DNA methylation patterns of genes related to ethylene biosynthesis and signaling were analyzed in tomato fruit.

Results In the present results, the expression level of LeEIN3, SIERF-A1 and LeERT10 decreased, and the expression level of LeCTR1 increased in tomato fruit stored at the low temperature of $11^{\circ} \mathrm{C}$. Meanwhile, the DNA methylation level of CpG island of LeEIN3, SIERF-A1 and LeERT10 increased, and the DNA methylation level of $\mathrm{CpG}$ island of LeCTR1 decreased in tomato fruit, respectively. The low temperature suppressed ethylene signaling via changing DNA methylation and gene expression, and delayed senescence of tomato fruit.

Conclusions The present study offered valuable information for understanding the role of DNA methylation in senescence of fruit, and provided a foundation for genetic modifying the epigenetic target sites and controlling fruit senescence.

\section{Introduction}

The cold chain is a supply chain of perishable products, which are stored and transported in a low temperature environment and a specific range of humidity conditions (Bogataj et al. 2005). In the food supply system, the cold chain has the capacity to maintain the quality and safety of food and reduce food loss, which was diffusely applied to delay fruit senescence and rot (Hu et al. 2019). Fruit senescence was aggravated through all kinds of internal and external factors, such as the insufficient energy supply, damage of membrane system, mechanical injury (Chen et al. 2020). In general, a decrease in product temperature by $10^{\circ} \mathrm{C}$ from environmental conditions doubles the shelf life, because the metabolism and the related physiological reactions of the product are slowed down (Wu et al. 2019). On the premise of maintaining normal life activities of agricultural products, the low temperature weakens postharvest physiological processes such as respiratory intensity and energy dissipation, delays fruit senescence, reduces postharvest losses; besides, the low temperature decreases the rate of biochemical reactions, such as browning reactions, lipid oxidation and pigment degradation; and inhibits growth and propagation of microorganisms (James and James 2010; Macheka et al. 2017). Fresh agricultural products are necessities for the daily lives of people and have a steady large-scale demand. In practice, postharvest losses are a primary obstacle in achieving sustainable fresh produce chains (Hodges et al. 2011).

DNA methylation is an epigenetic modification which adds a methyl group to cytosine bases (Schuebeler 2015). The DNA methylation participated in the regulation of gene expression during plant development and stress, and increased the adaptation of plants to various abiotic and biotic factors (Marfil et al. 2019; Zhang et al. 2010). The effect of external factors, such as low temperature, exogenous hormone and environmental stress, induced variation of DNA methylation and influenced gene expression (Klebaner et 
al. 2016). DNA methylation of nuclear genomes involved a more widespread range of methylation sites in plants than that in animals (Vanyushin and Ashapkin 2011). The CG, CHG, and $\mathrm{CHH}(\mathrm{H}$ is A, T or C) are common target sites of cytosine DNA methylation in plant genomes (Dubrovina and Kiselev 2016). In plants, DNA methylation of promoter regions ordinarily restrains transcription, but methylation in coding regions frequently either no affect the gene expression, or only has a medium influence (Zilberman et al. 2007). It had revealed that fruit senescence was under epigenetic control mediated by changes of DNA methylation and distribution, besides genetic and hormonal controls (Gapper er al. 2013). The changes of DNA methylation played an important role in the regulation of the tomato fruit softening and ripening (Zhong et al. 2013).

Tomato is among the most popular vegetables in the worldwide range. As the typical respiratory climacteric fruit, tomato can release ethylene to accelerate the senescence during storage and transportation stages. It is commonly harvested at the early mature stage, and supplies various regions by cold chain logistics (Tigist et al. 2013). Understanding the epigenetic mechanism of low temperature in delaying senescence of tomato fruit may provide valuable information for reducing postharvest fruit losses. In the present study, the changes of DNA methylation patterns of CpG islands of genes related to ethylene biosynthesis and signaling responded to low temperature in tomato fruit were analyzed.

\section{Materials And Methods}

Plant Material

Tomato (Solanum lycopersicum cv. Fen Gui Fei 455) fruit were harvested from modern agricultural science and technology demonstration park (Weifang, Shandong province, China) and transported to the laboratory. All fruit were sorted by means of size without physical injuries or infections, and were put in a plastic box to retain relative humidity (85-90\%), then stored at $11^{\circ} \mathrm{C}$ and $25^{\circ} \mathrm{C}$ for $0,3,6,9$ and $12 \mathrm{~d}$, respectively. The pericarp tissues were collected with well mixed to freeze in liquid nitrogen, and then were stored at $-80^{\circ} \mathrm{C}$.

Measurement of the Content of Total Chlorophyll and Lycopene

Frozen pericarp tissues were ground powder in the liquid nitrogen, then weigh $0.5 \mathrm{~g}$ powder and dissolve in $1.5 \mathrm{~mL}$ phosphate-buffered saline. Following the manufacturer's instructions, the content of total chlorophyll and lycopene was measured via Plant Total Chlorophyll ELISA Kit (Jining Biological Technology Co. Ltd., Shanghai, China) and Plant Lycopene ELISA Kit (Jining Biological Technology), respectively. Each sample was performed three replications, and the OD value was measured by spectrophotometer at a wavelength of $450 \mathrm{~nm}$.

Measurement of the Content of Vitamin C and Soluble Solid, the activities of Polygalacturonase (PG) and Cellulase 
The content of Vitamin C was measured by Plant Vitamin C ELISA Kit (Jining Biological Technology) as per the manufacturer's recommendations. The content of the soluble solid of tomato fruit was measured with a saccharimeter (WY032R). The activities of PG and cellulase were discovered by Plant Polygalacturonase ELISA Kit and Plant Cellulase ELISA Kit (Jingkang Biotechnology Co. Ltd., Shanghai, China), respectively. Each sample was performed three replications, and the OD value was measured by spectrophotometer at a wavelength of $450 \mathrm{~nm}$.

Measurement of energy status

The extract of tomato fruit was measured by HPLC (Waters e2695, America) equipped with a C18 inverting column $(5 \mu \mathrm{m} \times 250 \mathrm{~mm} \times 4.6 \mathrm{~mm})$ and UV $(254 \mathrm{~nm})$ detector via the method of Liu et al. (2006). The contents of ATP, ADP, and AMP were calculated through the external standard method and were denoted $\mathrm{mg} \mathrm{kg}^{-1}$ basis on fresh weight. $E C$ was calculated as: $E C=(A T P+0.5 \times A D P) /(A T P+A D P$ $+\mathrm{AMP})$.

Measurement of the Activities of Methylase and Demethylase

The activities of DNA methylase and demethylase was measured through the method of Pu et al. (2020).

Gene Expression Assay by RT-qPCR

The sequence of SIACS10, LeCTR1, LeEIN3, LeERT10 and SIERF-A1 genes (Supplementary) were inquired by NCBI web (https://www.ncbi.nlm.nih.gov/). The forward and reverse primers were devised according to the sequence of genes (Table 1). The reaction system was measured applying the iCycler iQ real-time PCR detection system (Bio-Rad, Berkeley, CA, USA) in three replicates and GAPDH was used as an internal reference. Following to the way of Livak and Schmittgen (2001), the relative expression level of the gene was calculated. 
Table 1

primers used for expression analyses of genes by qRT-PCR

\begin{tabular}{|lll|}
\hline Gene & primer & Sequence(5'-3') \\
\hline SIACS10 & Forward Primer & GGTCGCAGAGGCAATCAAGC \\
& Reverse Primer & GCCACAGCCCTCATTCTTATGC \\
\hline LeCTR1 & Forward Primer & AAGAGAACCTGGCATCCG \\
\hline LeEIN3 & Reverse Primer & TGAGGCAGACAGCGTTAC \\
\hline LeERT10 & Forward Primer & CGTGCCGTAGCGATTGAGC \\
\hline SIERF-A1 & Forward Primer & CACAGCCACTCAGAAGACCGTT \\
\hline Universal & Forward Primer & CCAAGGCTGTAGGGAAAGTGCTA \\
\hline GAPDH & Reverse Primer & TCAACCACGGACACATCAACAGT \\
\hline
\end{tabular}

DNA Methylation Level Analysis by Bisulfite Sequencing PCR (BSP)

DNA was purified by SDS solubilization and phenol-chloroform extraction. The primers were designed according to the sequence of the CpG island of genes (Table 2). Bisulfite mix reagent was added to highquality DNA, transformed on a circulating heater and completed DNA modification. After PCR reaction, product cloning was connected and converted in Trans-T1 Phage Resistant competent cell, and selectively grew on LB agar plate contain Ampicillin. Plasmids sequenced by Instrument (3730XL DNA analyzer, $\mathrm{ABI}$ Company). 
Table 2

primers used for DNA methylation analyses of genes by BSP

\begin{tabular}{|c|c|c|}
\hline Gene & primer & Sequence $\left(5^{\prime}-3^{\prime}\right)$ \\
\hline \multirow[t]{2}{*}{ SIACS10 } & Forward Primer & GGTTAGGTAGTTGATTGA(C/T)GTTATATT \\
\hline & Reverse Primer & CAAATACCTAAAATTACCСAATAATT \\
\hline \multirow[t]{2}{*}{ LeCTR1 } & Forward Primer & GTATTTGATTTGGATTTGATGGATT \\
\hline & Reverse Primer & TACCAATACATCAATCACAAAATCC \\
\hline \multirow[t]{2}{*}{ LeEIN3 } & Forward Primer & GTGGAGTTTAAGAAGTTGAGTATAAGT \\
\hline & Reverse Primer & САТСАТТTТСААСАТАТАСТТСААТАТ \\
\hline \multirow[t]{2}{*}{ LeERT10 } & Forward Primer & TGCAATCTCTATGTGATGAAATCAACT \\
\hline & Forward Primer & TCATAACTAGTCATTTCAAGTTCAAC \\
\hline \multirow[t]{2}{*}{ SIERF-A1 } & Forward Primer & T(C/T)GGAATTTGTGGTTTTATTAGAGA \\
\hline & Reverse Primer & АTTACTTTATTCCAC(G/A)AACAACCTTC \\
\hline
\end{tabular}

\section{Statistical Analysis}

The data were statistically analyzed using SPSS Statistics 17.0 software (SPSS Inc., Chicago, IL) and the graphs draw by GraphPad Prism 9 (GraphPad, San Diego, CA, USA). The value of mean and standard deviation (SD) was calculated. Two-way ANOVA and statistically significant differences (Tukey's HSD) for

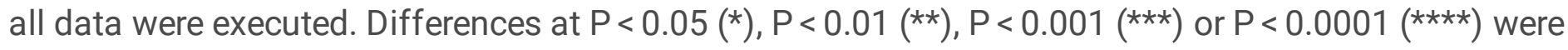
deemed as significant, and ns expressed no significant difference.

\section{Results}

Changes of Fruit Phenotype

Compared with the control fruit, low temperature treatment significantly delayed senescence of tomato fruit. The color of the control fruit became red at $3 \mathrm{~d}$. However, the color in low temperature treated fruit became red only until the $9 \mathrm{~d}$ (Fig. 1A-C).

The Content of Total Chlorophyll and Lycopene

The content of chlorophyll decreased with fruit senescence, and it was higher in low temperature treated fruit than those in control. The content of chlorophyll in low temperature treated fruit reduced from 33.13 to $27.56 \mathrm{mg} \mathrm{kg}^{-1}$ during storage from 3 to $12 \mathrm{~d}$, while the chlorophyll content in the control fruit reduced from 27.83 to $7.9 \mathrm{mg} \mathrm{kg}^{-1}$ (Fig. 1D). 
Simultaneously, the low temperature treated fruit had lower lycopene content compared with that in the control fruit. The content of lycopene in the control fruit was 2.11 times that of the low temperature treated fruit after stored for $3 \mathrm{~d}$. The lycopene content in low temperature treated fruit raised to $8.40 \mathrm{mg}$ $\mathrm{kg}^{-1}$ after stored for $9 \mathrm{~d}$, while the control fruit only increased to $4.52 \mathrm{mg} \mathrm{kg}^{-1}$ (Fig. 1E).

The Contents of Vitamin C and Soluble Solid

The content of vitamin $\mathrm{C}$ decreased with fruit senescence from 3 to $12 \mathrm{~d}$. The content of Vitamin $\mathrm{C}$ in the low temperature treated fruit reduced from 112.22 to $83.68 \mathrm{mg} \mathrm{kg}^{-1}$, while the control fruit reduced from 104.90 to $73.38 \mathrm{mg} \mathrm{kg}^{-1}$ (Fig. 2A). The content of soluble solid in control fruit decreased from 3.70$3.00 \%$ with fruit senescence during storage from 3 to $12 \mathrm{~d}$, but increased from $3.47-3.88 \%$ in low temperature treated fruit (Fig. 2B).

The Activities of PG and Cellulase

The activities of PG and cellulase increased significantly with fruit senescence. In low temperature treated fruit, the activities of PG and cellulase were both lower than those in control fruit. The PG activity in low temperature treated fruit raised from 313.03 to $479.43 \mathrm{U} \mathrm{kg}^{-1}$ during storage from 3 to $12 \mathrm{~d}$, and raised from 376.93 to $628.61 \mathrm{U} \mathrm{kg}^{-1}$ in control fruit (Fig. 2C). The activity of cellulase in low temperature treated fruit enhanced from 56.52 to $114.30 \mathrm{mU} \mathrm{kg}^{-1}$ during storage from 3 to $12 \mathrm{~d}$, and enhanced from 72.57 to $143.56 \mathrm{mU} \mathrm{kg}^{-1}$ in control fruit (Fig. 2D).

\section{Energy Status}

The contents of ATP in the low temperature treated fruit changed slightly over the entire storage, while decreased from 33.39 to $25.71 \mu \mathrm{g} \mathrm{g}^{-1}$ in the control fruit (Fig. 3A). The ADP content of both groups

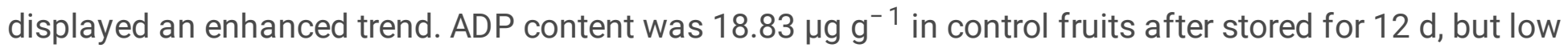
temperature treatment was $15.45 \mathrm{\mu g} \mathrm{g}^{-1}$ (Fig. 3B). The low temperature treatment effectively prevented the increase of AMP content. The AMP content of the control fruit raised from 7.28 to $43.36 \mathrm{\mu g} \mathrm{g}^{-1}$ during the whole storage, while the low temperature treatment only was $9.35 \mu^{-1} \mathrm{~g}^{-1}$ at the end of storage (Fig. 3C). According to the variations of ATP, ADP and AMP content, EC in tomato fruit reduced with prolonging storage time. The EC value of the low temperature treatment was 1.75 times that of the control after stored for $12 \mathrm{~d}$ (Fig. 3D).

The Activities of DNA Methylase and Demethylase

The activity of DNA methylase in low temperature treated fruit reached a maximum after stored for $6 \mathrm{~d}$, which was $551.33 \mathrm{U} \mathrm{kg}^{-1}$, and then decreased to $341.33 \mathrm{U} \mathrm{kg}^{-1}$ after stored for $12 \mathrm{~d}$. The activity of DNA methylase in the control fruit increased from 291.33 to $784.67 \mathrm{U} \mathrm{kg}^{-1}$ during storage from 6 to $12 \mathrm{~d}$ (Fig. 4A). The activity of DNA demethylase in low temperature treated fruit was lower than those in 
control fruit. The activity of demethylase in low temperature treated and control fruit reached the maximum of 459.78 and $644.57 \mathrm{U} \mathrm{kg}^{-1}$ after stored for $12 \mathrm{~d}$, respectively (Fig. 4B).

Genes Expression and DNA Methylation Levels

The expression level of the SIACS10 gene decreased with fruit senescence. During storage from 6 to 12 d, the expression level of SIACS10 in low temperature treated fruit reduced from 0.32 to 0.13 , while the control fruit reduced from 0.45 to 0.23 (Fig. 5A). Moreover, the methylation level of SIACS10 only appeared at $12 \mathrm{~d}$, and the methylation level of the control fruit was 4.29 times that of those in low temperature treatment (Fig. 5B and C).

The expression level of LeCTR 1 in the control fruit was 0.55 after stored for $6 \mathrm{~d}$. While the expression level of LeCTR1 in the low temperature treated fruit enhanced and then reduced at the whole storage period, reached a maximum value of 1.29 at $6 \mathrm{~d}$, and reduced to 1.05 at $12 \mathrm{~d}$ (Fig. 6A). The DNA methylation rate of $\mathrm{CpG}$ island of LeCTR1 in the low temperature treated fruit both were $0.6 \%$ at 6 and 12 $\mathrm{d}$, while DNA methylation rate of $\mathrm{CpG}$ island of LeCTR1 in control fruit merely arose at $6 \mathrm{~d}$ (Fig. $6 \mathrm{~B}$ and C).

The expression of LeEIN3 in low temperature treated fruit was down-regulated. The expression level of LeEIN3 of control fruit was 9.55 times than those in low temperature treatment after stored for $6 \mathrm{~d}$. The expression level of LeEIN3 of control fruit was 22.21 times than those in low temperature treatment after stored for $12 \mathrm{~d}$ (Fig. 6D). The DNA methylation rate of LeEIN3 in the low temperature treated fruit was higher than those in the control (Fig. 6E and F). The DNA methylation rate of LeEIN3 in low temperature treatment was 1.61 times than those in control after stored for $12 \mathrm{~d}$ (Fig. 6E).

The expression level of SIERF-A1 in both groups was up-regulated, but the low temperature treated fruit was slightly lower than those in control. The expression of SIERF-A1 in low temperature treated and control fruit was 1.49 and 1.91 at $12 \mathrm{~d}$, respectively (Fig. 7A). After stored for $6 \mathrm{~d}$, the methylation rate of $\mathrm{CpG}$ island of SIERF-A1 in low temperature treated and control fruit reached a peak value of $1.7 \%$ and $0.6 \%$, respectively. After stored for $12 \mathrm{~d}$, DNA methylation was not located in low temperature treated fruit, while the methylation rate of $\mathrm{CpG}$ island of SIERF-A1 in the control fruit reduced to $0.3 \%$ (Fig. $7 \mathrm{~B}$ and C).

The expression level of $L E E R T 10$ in the low temperature treated fruit was significantly lower than those in the control. The expression level of $L e E R T 10$ in low temperature treated fruit reduced from 0.24 to 0.10 during storage from 6 to $12 \mathrm{~d}$, while the control fruit reduced from 0.48 to 0.15 (Fig. 7D). The DNA methylation rate of $\mathrm{CpG}$ island of $\angle E E R T 10$ in the low temperature treated fruit was higher than those in control. The methylation rate of $\mathrm{CpG}$ island of $\angle E E R T 10$ in low temperature treated fruit increased to $1.7 \%$ after stored for $12 \mathrm{~d}$, while DNA methylation was not located in the control (Fig. 7E and F).

\section{Discussion}

In cold chain logistics, low temperature plays an important role in transporting perishable foods from production to consumption while ensuring the quality and safety of foods. Low temperature storage 
could significantly reduce the expression level of numerous genes related to the aroma volatiles synthesis during the storage of tomato fruit (Zou et al. 2018). The postharvest fruit, as independent existence, infinitely depleted nutrient to result in irreversible senescence until death (Wang et al. 2021a). In the present study, the low temperature $\left(11^{\circ} \mathrm{C}\right)$ treatment effectively delayed the senescence of tomato fruit (Fig. 1A-C). The content of total chlorophyll in the low temperature treated fruit was higher than that in the control fruit, and the lycopene content in the low temperature treated fruit was lower than those in control fruit, which cause a noticeable color difference on tomato fruit peel (Fig. 1D and E).

The fruit ripening and senescence connected with degradation of the cell wall, which the enhancement of water-soluble pectin and the reduction cellulose gradually caused fruit to soften (Wang et al. 2021b). Cellulose, as the main component of plant cell walls, can maintain the strength of the cell wall (Wang et al. 2021b). PG was the major hydrolysis enzyme of modifying pectin, which can further decompose pectin acid-generating from that pectin methylesterase (PME) catalyzed pectin demethylation, finally resulting in the structure of cell wall loosening and fruit softening (Rugkong et al. 2010). The better fruit quality was maintained by lower fruit softening enzyme activity (Adhikary et al. 2021). In this study, the $P G$ and cellulase activities in the low temperature treated fruit were also lower than those in the control fruit (Fig. 2C and D), which indicated that low temperature effectively restrained pectin degradation and cell wall injure to delay senescence and soften of tomato fruit.

Similarly, the higher energy consumption can cause the increase of respiratory rate in postharvest fruit to accelerate the development of senescence and disease ( $\mathrm{Li}$ et al. 2020). ATP was the center of energy conversion within cells, which produce chemical energy through catabolic and anabolic that was used immediately in plant (Vichaiya et al. 2020). The membrane system integrity was connected with cellular energy status. The continuous consumption of cellular energy may lead to membrane damage, while higher-level ATP content can preserve the membrane potential and maintain the membrane system integrity, to delay fruit senescence and to retain qualities (Aghdam et al. 2018). The higher accumulation of energy-matter in kiwifruit could keep an integral cell membrane (Wang et al. 2020). In this study, low temperature treated fruit retained higher ATP content and EC level compared with the control fruit (Fig. 3), which may be contributing to restraining the activities of PG and $C E$, to delay the fruit senescence. Previous reports showed that MeJA treatment delays the postharvest softening of blueberry and pineapple fruit by altering cell wall modification and energy metabolism (Boonyaritthongchai and Supapvanich 2017). The senescence process of the litchis (Tang et al. 2020), longans (Li et al. 2020) and broccoli (Huang et al. 2021) accompany the reduction of ATP, ADP content and EC level, and the enhancement of AMP.

The process of fruit ripening and senescence is closely related to the biosynthetic and signaling pathway of ethylene. Among the biosynthetic pathways upstream of ethylene, ACS and ACO enzymes are encoded by multigene families. They were differentially expressed in various tissues at different developmental phases (Nakatsuka et al. 1998). The ETR and CTR1 both are a negative regulatory element in the ethylene signaling pathway, which can activate the positive regulatory factor EIN2, pass the downstream EIN3/EILs, promote the expression of the transcription factor ERF and transcript ERT, and ultimately 
express ethylene-related response genes (Guo et al. 2018; Hu et al. 2012; Trentmann 2000). DNA methylation and demethylation were requested for both the activation of ripening induced genes and the suppression of ripening repressed genes (Lang et al. 2017).

As one of the key enzymes, ACS tightly regulated ethylene biosynthesis (Barry and Grierson, 2000). Among the ACS genes that have been cloned from tomato, LeACS2 and LeACS4 are mainly expressed during the climacteric phase of tomato fruit, resulting in a large amount of ethylene and a characteristic of auto-catalytic ethylene of system II (Anugerah et al. 2015). During the natural ripening of watermelon, the expression of two ACS isoforms, Cla022653 and Cla011522, were significantly up-regulated in 97103 flesh, which play an important role in ethylene biosynthesis and ripening control in watermelon flesh (Zhou et al. 2016). Here, low temperature treatment reduced the expression of the S/ACS10 gene (Fig. 5), which might involve inhibiting the ethylene biosynthesis and delaying the senescence of tomato fruit. The DNA methylation level of the $\mathrm{CpG}$ island of SIACS10 in low temperature treated fruit was reduced compared with control, the changes of seven DNA methylation sites in the CpG island of SIACS10 might have no critical importance on its expression.

CTR1 is a negative regulator of ethylene signaling, and its interaction with ETR1 is required for the negative regulation of ethylene signaling (Kieber et al. 1993). LeCTR1 silenced tomato plants induce the expression of ethylene-responsive genes, such as ERF5, EIN2, and EIN3 (Chandan et al. 2019). The amino acid sequence of MhCTR1 showed 55\% homology to LeCTR1, as well as the changes of MhCTR1 expression in the pulp were closely related to the regulation of the banana senescence process (Hu et al. 2012). Here, the DNA methylation level of CpG island of LeCTR1 in the low temperature treated fruit decreased than those in control fruit at $6 \mathrm{~d}$, and by which raised the expression of the LeCTR1 gene (Fig. 6A-C), and might suppress ethylene signaling. These may be one of the mechanisms of low temperature delayed senescence of tomato fruit.

EIN3 is a key to activate the ethylene transcription factors ERF. EIN3 proteins bind directly to primary ethylene response element (PERE) motifs to regulate gene expression (Solano et al. 1998). In Arabidopsis, EIN3, ORE1 and CCG work together to regulate ethylene-mediated chlorophyll degradation during leaf senescence (Qiu et al. 2015). CpEIN3a was found to increase and participate in carotenoid accumulation during fruit ripening and senescence in papaya (Fu et al. 2017). Compared with the control, low temperature treatment raised the DNA methylation level of LeEIN3 in tomato fruit, reduced the expression of LeEIN3 (Fig. 6D-E), and suppressed ethylene signaling. The increased DNA methylation of LeEIN3 may be involved in low temperature delaying senescence of tomato fruit.

ERFs are DNA-binding proteins belonging to the AP2/ERF family, and coordinate transcription of diverse ethylene-responsive genes (Gu et al. 2002). The expression levels of the four ERF genes in pear increased significantly during fruit senescence. Pbr012024.1 responded to the ethylene signal, and the Pbr022708.1 can be induced by ethylene and is the only ethylene response factor that regulates fruit senescence (Hao et al. 2017; Xu et al. 2018). In tomato, overexpression of LeERF1 accelerated fruit senescence (Li et al. 2007). LeERF2 is induced by ethylene and suppressed in ripening inhibited mutants (Wu et al. 2002). 
Here, compared with that in control fruit, the DNA methylation levels of SIERF-A1 in low temperature treated fruit reached maximum at $6 \mathrm{~d}$, the expression of SIERF-A1 gene was significantly decreased at 6 and $12 \mathrm{~d}$ (Fig. 7A-C), and by which the ethylene signaling might be suppressed. These may be one of the mechanisms of low temperature delayed tomato fruit senescence.

$E R T$ encodes transcripts that regulate ethylene transcription regulation, and participates in the cascade of constitutive cellular factors related to ethylene signal transduction (Trentmann 2000). 49 putative ethylene-responsive transcripts (ERTs) were isolated from etiolated seedlings of Arabidopsis, and ethylene-regulated nuclear protein (ERN) was isolated and cloned from ERT2. Evidence had shown that ERN1 encoded downstream targets of EIN3 protein as did ERF1 (Solano et al. 1998). Hot water treatment delayed the ripening of tomato fruit, which process accompanies the reduction of the expression level of LeERT10 and increase of methylation level (Pu et al. 2020). In the present study, the low temperature treatment enhanced the DNA methylation level of $L E E R T 10$ and significantly reduced the expression of the LeERT10 gene in tomato fruit (Fig. 7D-F), and suppressed ethylene signaling. The enhanced DNA methylation level of $L E E R T 10$ may be involved in low temperature delaying senescence of tomato fruit.

\section{Conclusion}

The low temperature changed the DNA methylation levels of CpG island of LeCTR1, LeEIN3, SIERF-A1 and LeERT10 in tomato fruit, impacted their expression and suppressed ethylene signaling, by which delayed fruit senescence. The study offered useful information for comprehending the role of DNA methylation for fruit senescence, and provided a foundation for genetically modifying the epigenetic target sites and controlling fruit senescence.

\section{Declarations}

Funding This study was supported by the National Natural Science Foundation of China (31872160).

Conflicts of Interest The authors confirm that they have no conflicts of interest with respect to the work described in this manuscript.

\section{References}

1. Adhikary T, Gill PPS, Jawandha SK et al (2021) Efficacy of postharvest sodium nitroprusside application to extend storability by regulating physico-chemical quality of pear fruit. Food Chem 346: 128934. https://doi.org/10.1016/j.foodchem.2020.128934

2. Aghdam MS, Jannatizadeh A, Luo $Z$ et al (2018) Ensuring sufficient intracellular ATP supplying and friendly extracellular ATP signaling attenuates stresses, delays senescence and maintains quality in horticultural crops during postharvest life. Trends Food Sci Tech 76: 67-81.

https://doi.org/10.1016/j.tifs.2018.04.003

Page $11 / 23$ 
3. Anugerah PR, Dwivany F, Esyanti RR (2015) Expression Study of LeGAPDH, LeACO1, LeACS1A, and LeACS2 in Tomato Fruit (Solanum lycopersicum). Hayati J Biosciences 22: 191-196. https://doi.org/10.1016/j.hjb.2016.01.004

4. Barry CS, Grierson LT (2000) The Regulation of 1-Aminocyclopropane-1-Carboxylic Acid Synthase Gene Expression during the Transition from System-1 to System-2 Ethylene Synthesis in Tomato. Plant Physiol 123: 979-986. https://doi.org/10.1104/pp.123.3.979

5. Boonyaritthongchai P, Supapvanich S (2017) Effects of methyl jasmonate on physicochemical qualities and internal browning of 'Queen' pineapple fruit during cold storage. Hortic Environ Biotechnol 58: 479-487. https://doi.org/10.1007/s13580-017-0362-3

6. Bogataj M, Bogataj L, Vodopivec R (2005) Stability of perishable goods in cold logistic chains. Int J Prod Econ 93-94: 345-356. https://doi.org/10.1016/j.ijpe.2004.06.032

7. Chandan RK, Singh AK, Patel S et al (2019) Silencing of tomato CTR1 provides enhanced tolerance against Tomato leaf curl virus infection. Plant Signal Behav 14: 1-7. https://doi.org/10.1080/15592324.2019.1565595

8. Chen YH, Sun JZ, Lin HT et al (2020) Salicylic acid reduces the incidence of Phomopsis longanae Chi infection in harvested longan fruit by affecting the energy status and respiratory metabolism. Postharvest Biol Technol 160: 111035. https://doi.org/10.1016/j.postharvbio.2019.111035

9. Dubrovina AS, Kiselev KV (2016) Age-associated alterations in the somatic mutation and DNA methylation levels in plants. Plant Biology 18: 185-196. https://doi.org/10.1111/plb.12375

10. Fu CC, Han YC, Kuang JF et al (2017) Papaya CpEIN3a and CpNAC2 co-operatively regulate carotenoid biosynthesis-related genes $C p P D S 2 / 4, C p L C Y$-e and $C p C H Y-b$ during fruit ripening. Plant Cell Physiol 58: 2155-2165. https://doi.org/10.1093/pcp/pcx149

11. Gapper NE, Mcquinn RP, Giovannoni JJ (2013) Molecular and genetic regulation of fruit ripening. Plant Mol Biol 82, 575-591. https://doi.org/10.1007/s11103-013-0050-3

12. Gu YQ, Wildermuth MC, Chakravarthy S et al (2002) Tomato transcription factors pti4, pti5, and pti6 activate defense responses when expressed in Arabidopsis. Plant Cell 14: 817-831. https://doi.org/10.1105/tpc.000794

13. Guo X, Zhang Y, Tu Y et al (2018) Overexpression of an EIN3-binding F-box protein2-like gene caused elongated fruit shape and delayed fruit development and ripening in tomato. Plant Sci 272: 131-141. https://doi.org/10.1016/j.plantsci.2018.04.016

14. Hao PP, Wang GM, Cheng HY et al (2017) Transcriptome analysis unravels an ethylene response factor involved in regulating fruit ripening in pear. Physiol Plantarum 163: 124-135. https://doi.org/10.1111/ppl.12671

15. Hodges RJ, Buzby JC, Bennett B (2011) Postharvest losses and waste in developed and less developed countries: Opportunities to improve resource use. J Agr Sci 149: 37-45. https://doi.org/10.1017/S0021859610000936

16. Huang H, Wang D, Belwal T et al (2021) A novel W/O/W double emulsion co-delivering brassinolide and cinnamon essential oil delayed the senescence of broccoli via regulating chlorophyll 
degradation and energy metabolism. Food Chem 356: 129704.

https://doi.org/10.1016/j.foodchem.2021.129704

17. Hu HL, Do YY, Huang PL (2012) Expression profiles of a MhCTR1 gene in relation to banana fruit ripening. Postharvest Biol Technol 56: 47-55. https://doi.org/10.1016/j.plaphy.2012.04.001

18. Hu GW, Mu XZ, Xu M et al (2019) Potentials of GHG emission reductions from cold chain systems: Case studies of China and the United States. J Clean Prod 239: 118053.

https://doi.org/10.1016/j.jclepro.2019.118053

19. James SJ, James C (2010) The food cold-chain and climate change. Food Res Int 43: 1944-1956. https://doi.org/10.1016/j.foodres.2010.02.001

20. Kieber JJ, Rothenberg M, Roman G et al (1993) CTR1, a negative regulator of the ethylene response pathway in Arabidopsis, encodes a member of the Raf family of protein kinases. Cell 72: 427-441. https://doi.org/10.1016/0092-8674(93)90119-B

21. Klebaner D, Huang Y, Hui Q et al (2016) X chromosome-wide analysis identifies DNA methylation sites influenced by cigarette smoking. Clin Epigenetics 8. https://doi.org/10.1186/s13148-016-01892

22. Lang Z, Wang Y, Tang $\mathrm{K}$ et al (2017) Critical roles of DNA demethylation in the activation of ripeninginduced genes and inhibition of ripening-repressed genes in tomato fruit. P Natl Acad Sci USA 114: 4511-4519. https://doi.org/10.1073/pnas.1705233114

23. Li YC, Zhu BZ, Xu WT et al (2007) LeERF1 positively modulated ethylene triple response on etiolated seedling, plant development and fruit ripening and softening in tomato. Plant Cell Rep 26: 19992008. https://doi.org/10.1007/s00299-007-0394-8.

24. Li ML, Zheng QP, Lin HT et al (2020) The influence of ATP treatment on energy dissipation system in postharvest longan fruit during senescence. Postharvest Biol Technol 164: 111154. https://doi.org/10.1016/j.postharvbio.2020.111154

25. Liu H, Jiang YM, Luo YB et al (2006) A simple and rapid determination of ATP, ADP and AMP concentrations in pericarp tissue of litchi fruit by high performance liquid chromatography. Food Technol Biotech 44: 531-534. https://doi.org/10.1016/j.fm.2005.11.001

26. Livak KJ, Schmittgen TD (2001) Analysis of relative gene expression data using real-time quantitative PCR. Methods 25: 402-408. https://doi.org/10.1006/meth.2001.1262

27. Macheka L, Spelt E, van der Vorst JGAJ et al (2017) Exploration of logistics and quality control activities in view of context characteristics and postharvest losses in fresh produce chains: A case study for tomatoes. Food Control 77: 221-234. https://doi.org/10.1016/j.foodcont.2017.02.037

28. Marfil C, Ibañez V, Alonso R et al (2019) Changes in grapevine DNA methylation and polyphenols content induced by solar ultraviolet-B radiation, water deficit and abscisic acid spray treatments. Plant Physiol Bioch 135: 278-294. https://doi.org/10.1016/j.plaphy.2018.12.021

29. Nakatsuka A, Murachi S, Okunishi H et al (1998) Differential expression and internal feedback regulation of 1-aminocyclopropane-1-carboxylate synthase, 1-aminocyclopropane-1-carboxylate 
oxidase, and ethylene receptor genes in tomato fruit during development and ripening. Plant Physiol 118: 1295-1305. https://doi.org/10.1104/pp.118.4.1295

30. Pu HL, Shan SS, Wang ZQ et al (2020) Dynamic changes of DNA methylation induced by heat treatment were involved in ethylene signal transmission and delayed the postharvest ripening of tomato fruit. J Agr Food Chem 68: 8976-8986. https://doi.org/10.1021/acs.jafc.0c02971

31. Qiu K, Li ZP, Yang Z et al (2015) EIN3 and ORE1 Accelerate degreening during ethylene-mediated leaf senescence by directly activating chlorophyll catabolic genes in Arabidopsis. Plos Genet 11: e1005399. https://doi.org/10.1371/journal.pgen.1005399

32. Rugkong A, Rose JKC, Lee SJ et al (2010) Cell wall metabolism in cold-stored tomato fruit. Postharvest Biol Technol 57: 106-113. https://doi.org/10.1016/j.postharvbio.2010.03.004

33. Schuebeler D (2015) Function and information content of DNA methylation. Nature 517: 321-326. https://doi.org/10.1038/nature14192

34. Solano R, Stepanova A, Chao Q et al (1998) Nuclear events in ethylene signaling: a transcriptional cascade mediated by ETHYLENE-INSENSITIVE3 and ETHYLENE-RESPONSE-FACTOR1. Gene Dev 12: 3703-3714. https://doi.org/10.1101/gad.12.23.3703

35. Tang RF, Zhou YJ, Chen ZS et al (2020) Involvement of miRNA-mediated anthocyanin and energy metabolism in the storability of litchi fruit. Postharvest Biol Technol. 165: 111200. https://doi.org/10.1016/j.postharvbio.2020.111200

36. Tigist M, Workneh TS, Woldetsadik K (2013) Effects of variety on the quality of tomato stored under ambient conditions. J Food Sci Tech 50: 477-486. https://doi.org/10.1007/s13197-011-0378-0

37. Trentmann SM (2000) ERN1, a novel ethylene-regulated nuclear protein of Arabidopsis. Plant Mol Biol 44, 11-25. https://doi.org/10.1023/A:1006438432198

38. Vanyushin BF, Ashapkin VV (2011) DNA methylation in higher plants: Past, present and future. BBAGene Regul. Mech. 1809: 360-368. https://doi.org/10.1016/j.bbagrm.2011.04.006

39. Vichaiya T, Uthaibutra J, Saengnil K (2020) Gaseous chlorine dioxide increases energy status and energy metabolismrelated enzyme activities leading to reduction in pericarp browning of longan fruit during storage. Sci Hortic 263: 109118. https://doi.org/10.1016/j.scienta.2019.109118

40. Wang F, Yang QZ, Zhao QF et al (2020) Roles of antioxidant capacity and energy metabolism in the maturitydependent chilling tolerance of postharvest kiwifruit. Postharvest Biol Technol 168: 111281. https://doi.org/10.1016/j.postharvbio.2020.111281

41. Wang D, Ma Q, Li D et al (2021a) Moderation of respiratory cascades and energy metabolism of fresh-cut pear fruit in response to high $\mathrm{CO}_{2}$ controlled atmosphere. Postharvest Biol Technol 172: 111379. https://doi.org/10.1016/j.postharvbio.2020.111379

42. Wang HB, Cheng $X$, Wu C et al (2021b) Retardation of postharvest softening of blueberry fruit by methyl jasmonate is correlated with altered cell wall modification and energy metabolism. Sci Hortic 276. https://doi.org/109752. 10.1016/j.scienta.2020.109752 
43. Wu K, Tian L, Hollingworth J et al (2002) Functional analysis of tomato Pti4 in Arabidopsis. Plant Physiol 128: 30-37. https://doi.org/10.1104/pp.010696

44. Wu W, Beretta C, Cronje P et al (2019) Environmental trade-offs in fresh-fruit cold chains by combining virtual cold chains with life cycle assessment. Appl Energ 254: 113586. https://doi.org/10.1016/j.apenergy.2019.113586

45. Xu HY, Chen YY, Wang LB et al (2018) Transcriptome analysis reveals a regulation of ethyleneinduced post-harvest senescence in pear fruit. Sci Hortic 240: 585-591. https://doi.org/10.1016/j.scienta.2018.05.019

46. Zhang MS, Kimatu JN, Xu KZ et al (2010) DNA cytosine methylation in plant development. J Genet Genomics 37: 1-12. https://doi.org/10.1016/S1673-8527(09)60020-5

47. Zhong SL, Fei ZJ, Chen YR et al (2013) Single-base resolution methylomes of tomato fruit development reveal epigenome modifications associated with ripening. Nat Biotechnol 31, 154-159. https://doi.org/10.1038/nbt.2462

48. Zhou M, Guo SG, Zhang J et al (2016) Comparative dynamics of ethylene production and expression of the $A C S$ and $A C O$ genes in normal-ripening and non-ripening watermelon fruits. Acta Physiol Plant 38: 228. https://doi.org/10.1007/s11738-016-2248-x

49. Zilberman D, Gehring M, Tran RK et al (2007) Genome-wide analysis of Arabidopsis thaliana DNA methylation uncovers an interdependence between methylation and transcription. Nat Genet 39: 6169. https://doi.org/10.1038/ng1929

50. Zou J, Chen J, Tang $\mathrm{N}$ et al (2018) Transcriptome analysis of aroma volatile metabolism change in tomato (Solanum lycopersicum) fruit under different storage temperatures and 1-MCP treatment. Postharvest Biol Technol 135: 57-67. https://doi.org/10.1016/j.postharvbio.2017.08.017

\section{Figures}




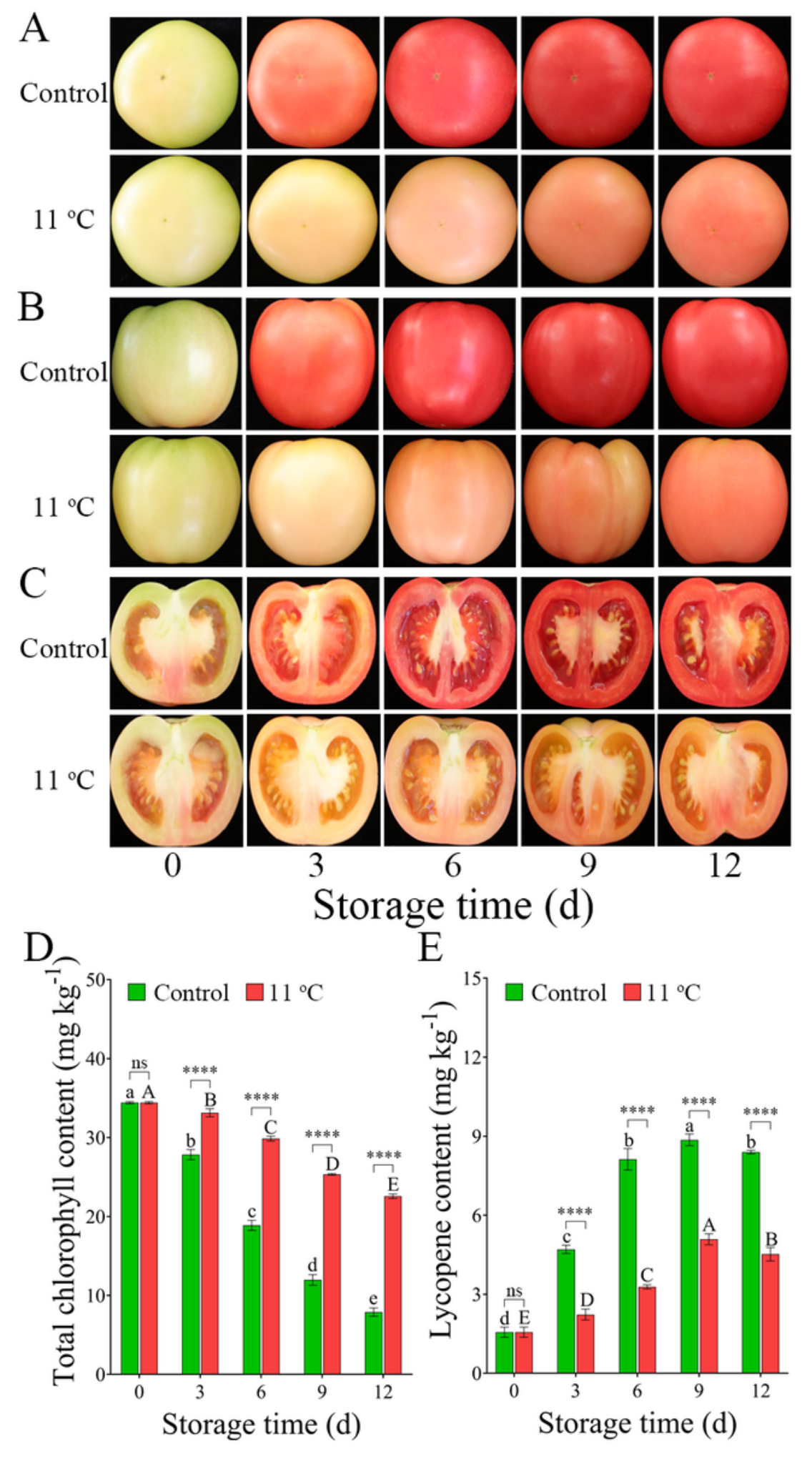

Figure 1

Senescence changes of tomato fruit. (A) Senescence phenotypic characterization of the exterior of tomato fruit. (B) Senescence phenotypic characterization of the flank of tomato fruit. (C) Senescence phenotypic characterization of the interior of tomato fruit. (D) Total chlorophyll content. (E) Lycopene content. Vertical bars represent standard deviations of the means, $n=3$. Asterisks indicate statistical 


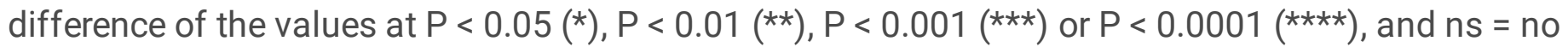
significant.
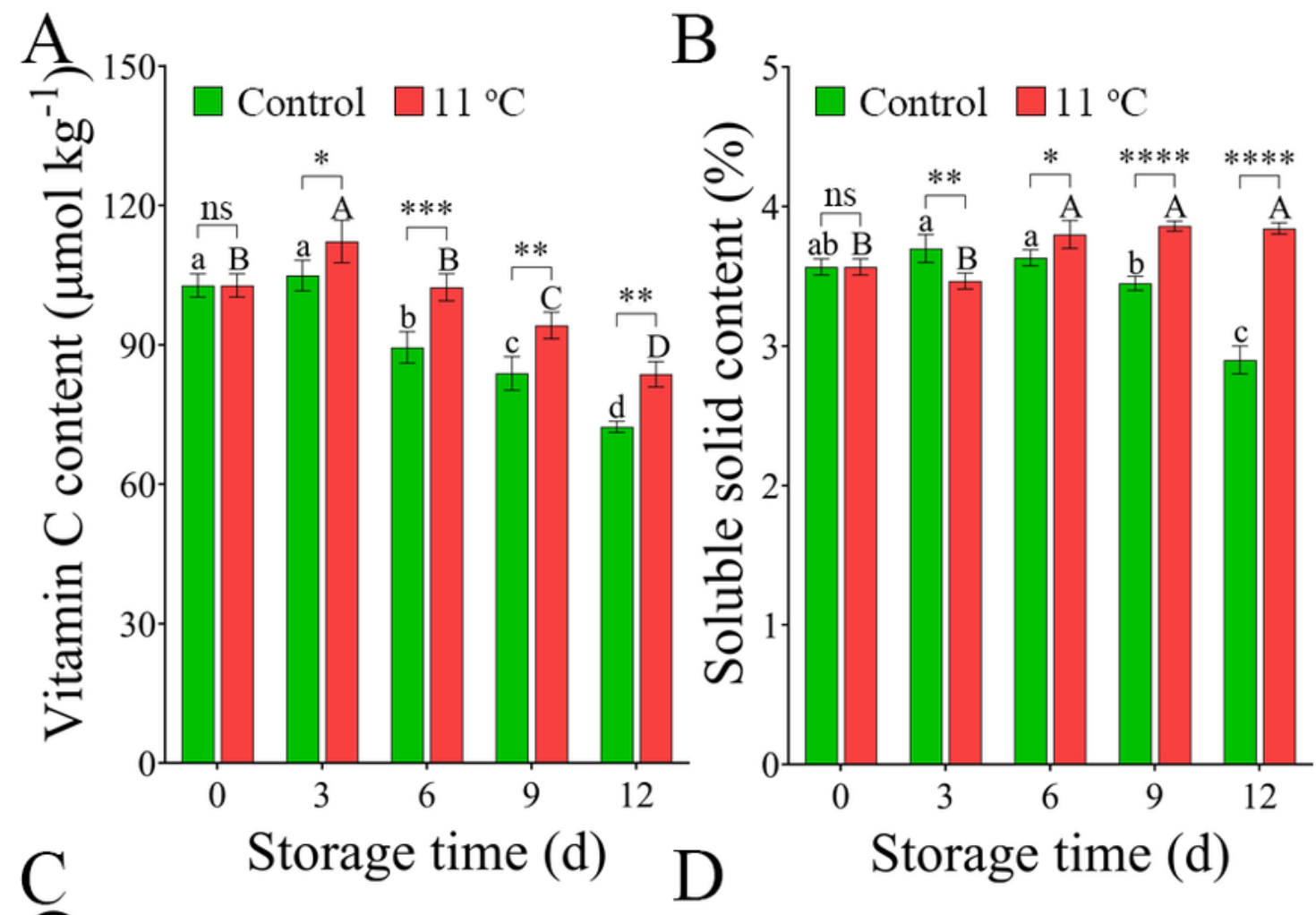

D Storage time (d)

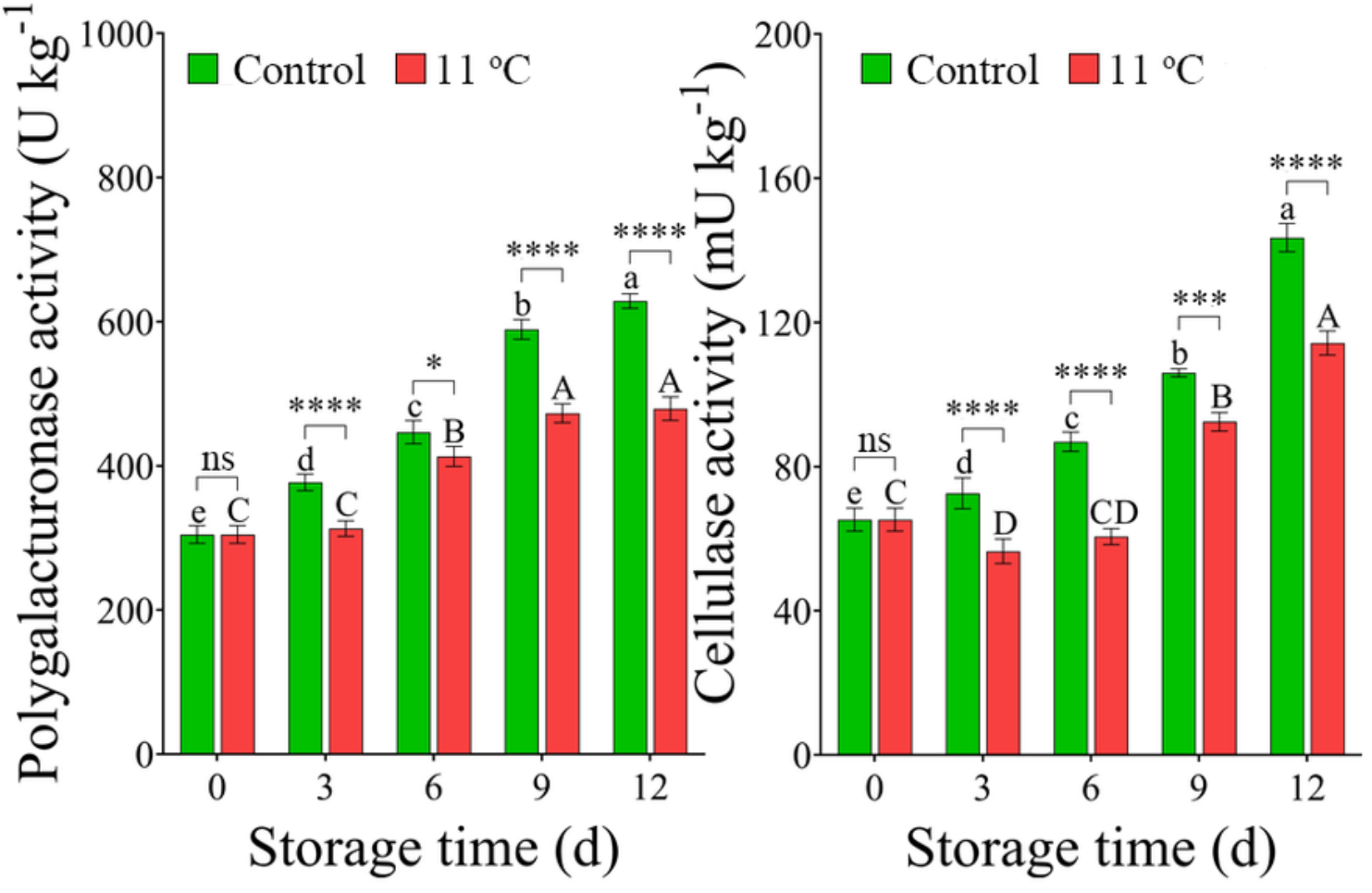

Figure 2

The change of vitamin $C$ content (A), soluble solid content (B), polygalacturonase activity (C), and cellulase activity (D) in tomato fruit. Vertical bars represent standard deviations of the means, $n=3$. 
Asterisks indicate statistical difference of the values at $\mathrm{P}<0.05\left({ }^{*}\right), \mathrm{P}<0.01\left({ }^{\star *}\right), \mathrm{P}<0.001\left(^{(\star \star}\right)$ or $\mathrm{P}<$ $0.0001(\star \star \star *)$, and ns = no significant.
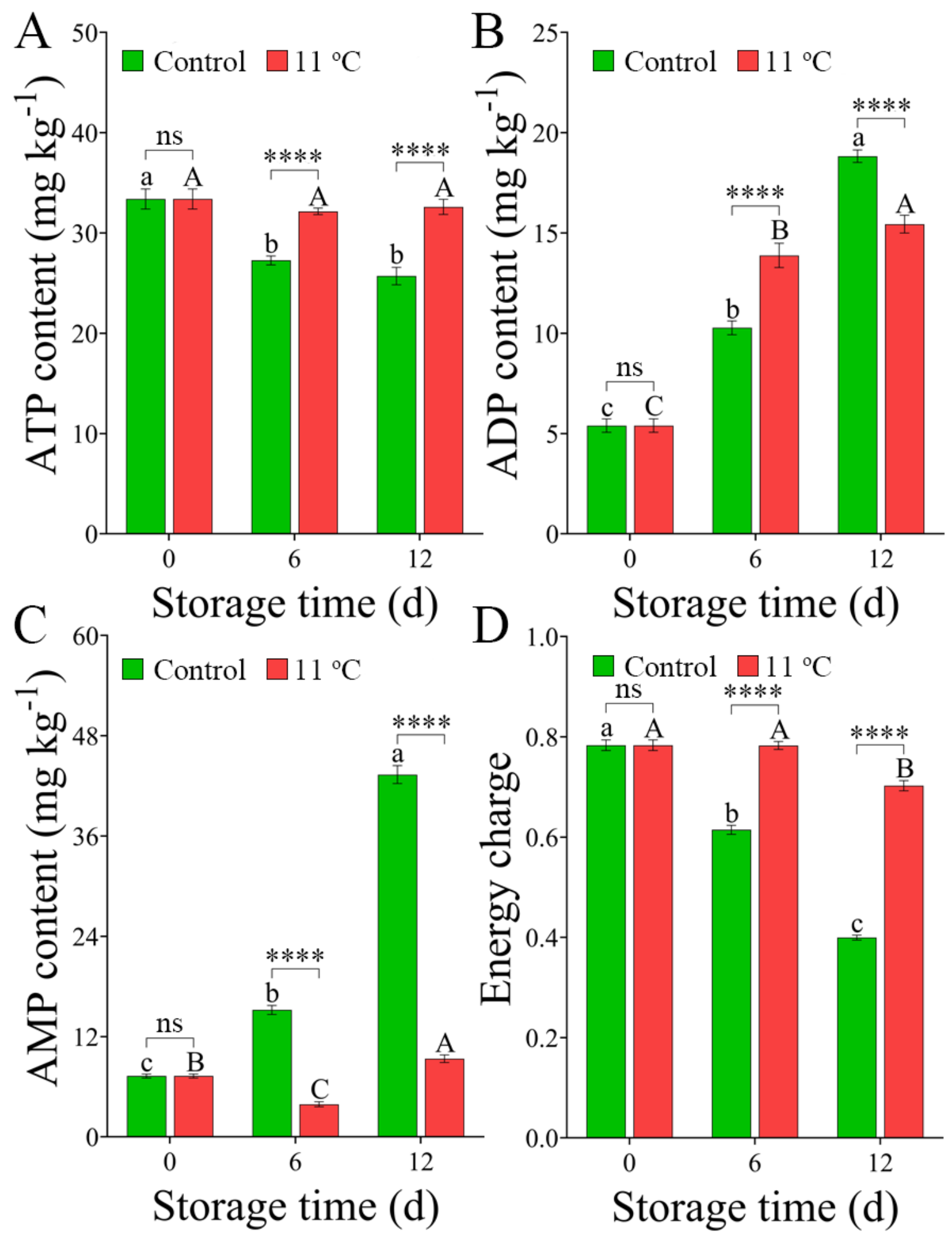

Figure 3

The change of ATP content (A), ADP content (B), AMP content (C), and Energy charge (D) in tomato fruit. Vertical bars represent standard deviations of the means, $n=3$. Asterisks indicate statistical difference of the values at $\mathrm{P}<0.05(*), \mathrm{P}<0.01(* *), \mathrm{P}<0.001{ }^{(* \star}{ }^{(*)}$ or $\left.\mathrm{P}<0.0001{ }^{(* \star *}\right)$, and $\mathrm{ns}=$ no significant. 

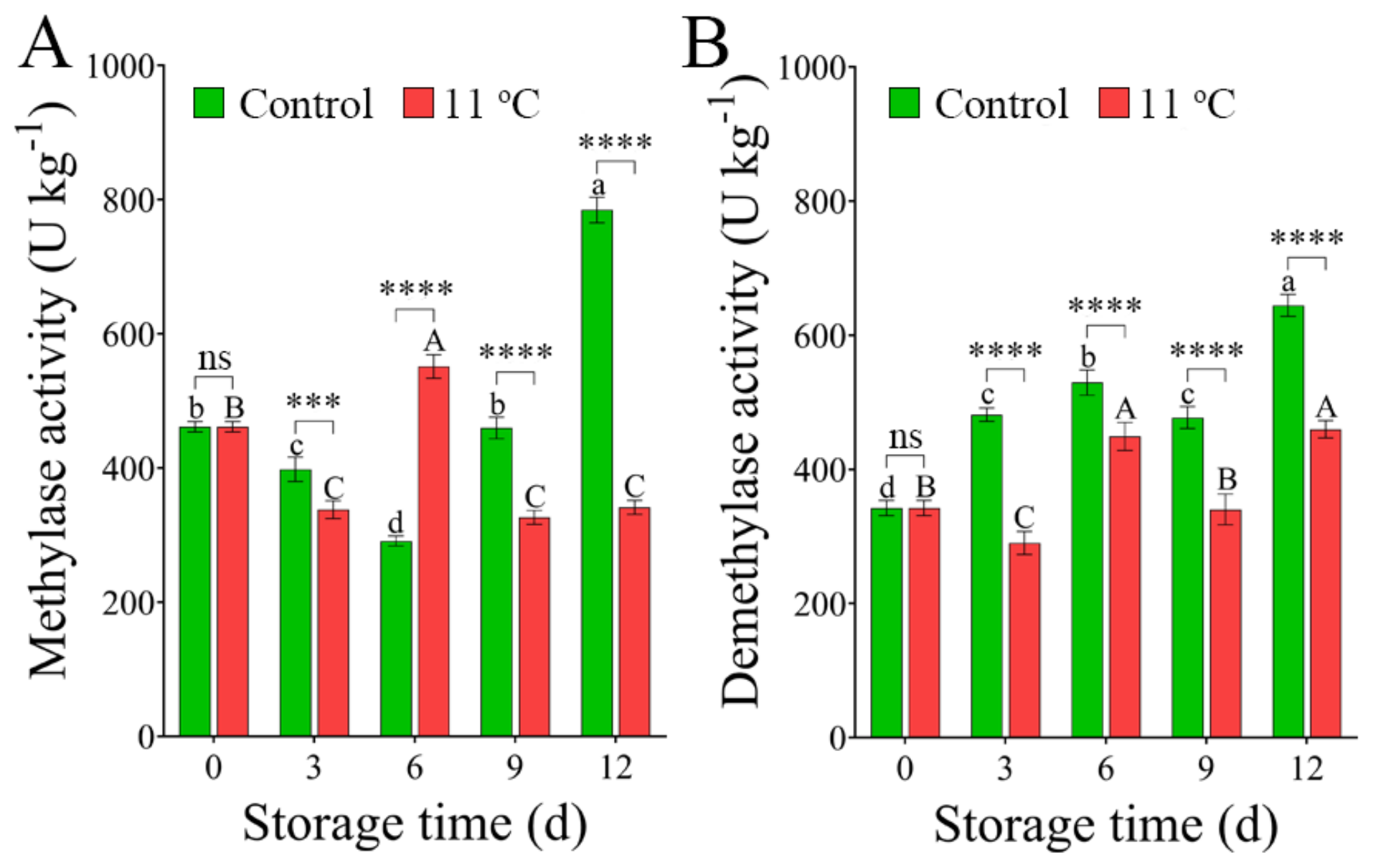

Figure 4

The change of the Methylase activity (A) and Demethylase activity (B) in tomato fruit. Vertical bars represent standard deviations of the means, $n=3$. Asterisks indicate statistical difference of the values at

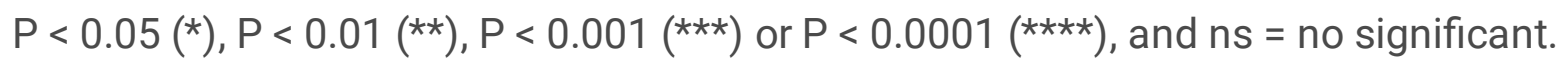




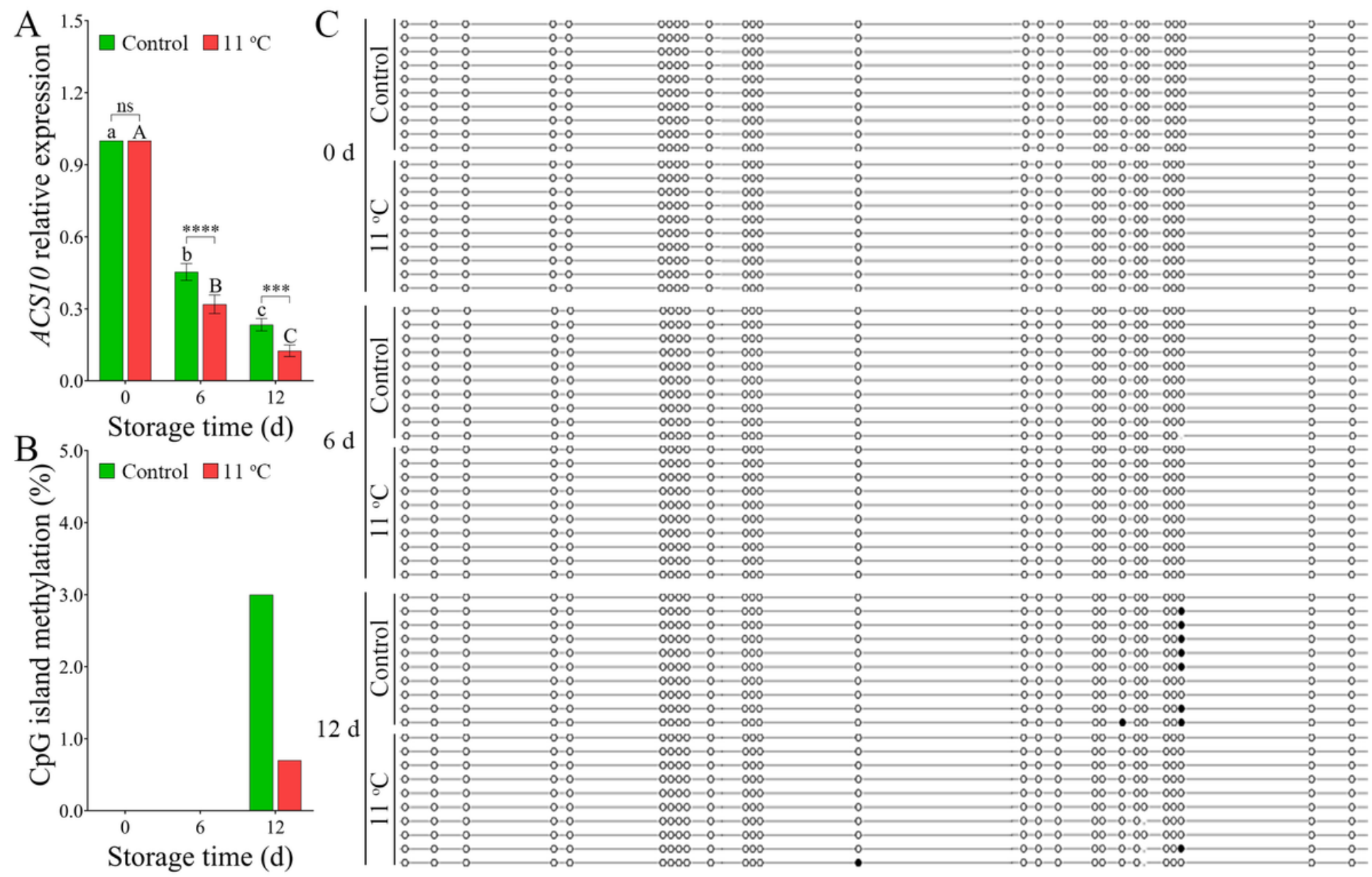

Figure 5

Expression level and DNA methylation rate of SIACS10 in tomato fruit. (A) Relative expression level. (B) DNA methylation rate. (C) Changes of DNA methylation sites. Each line represents 1 clone, and 1 circle represents $1 \mathrm{CpG}$ site. The black circle represents the methylated CG, and the white circle represents the unmethylated CG. Vertical bars represent standard deviations of the means, $n=3$. Asterisks indicate

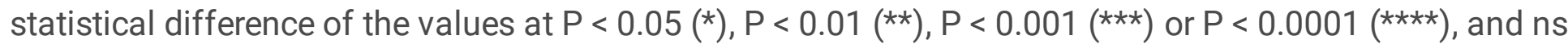
= no significant. 

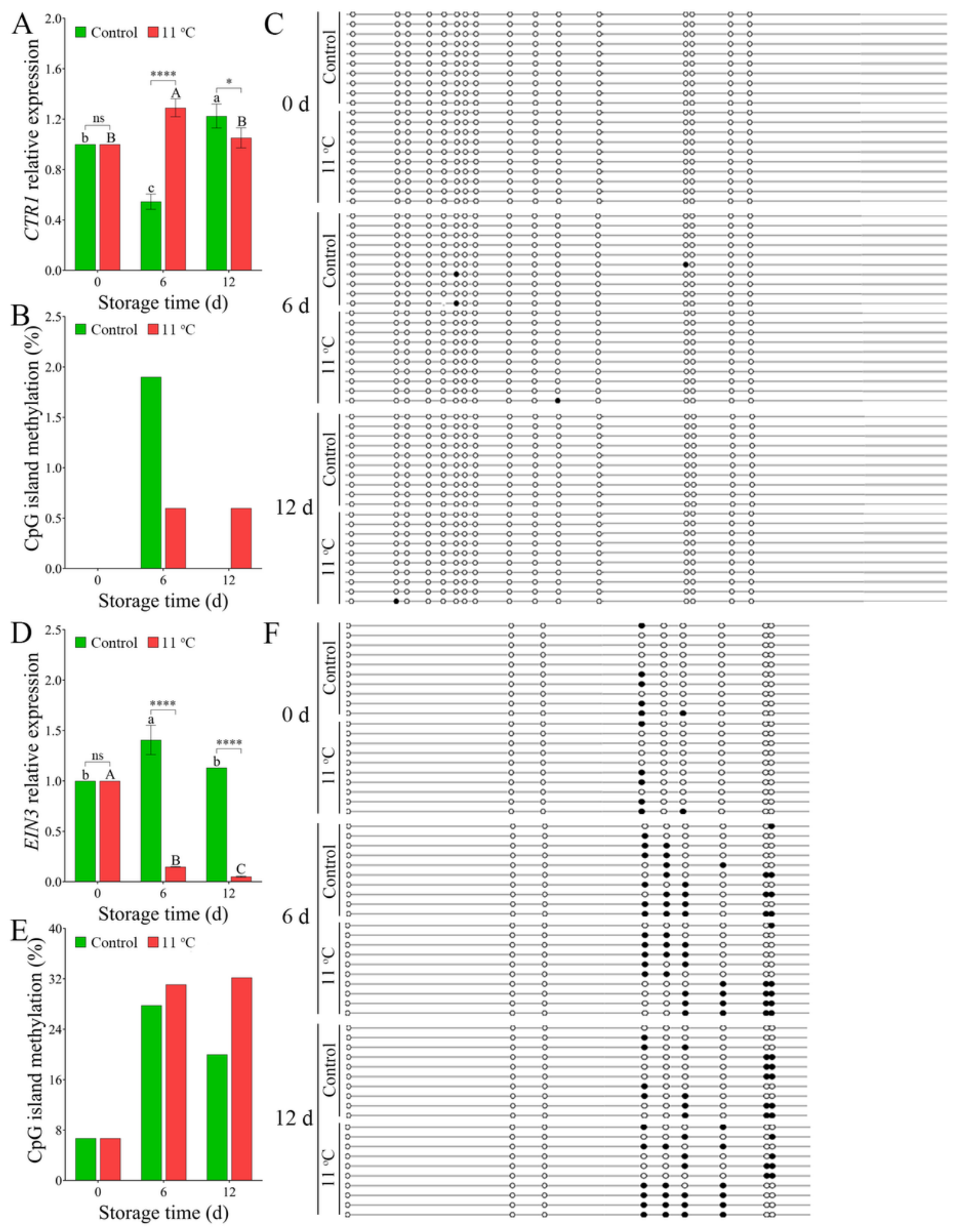

\section{Figure 6}

Expression level and DNA methylation rate of LeCTR1 and LeEIN3 in tomato fruit. (A) Relative expression level of LeCTR1. (B) DNA methylation rate of CpG island of LeCTR1. (C) Changes of DNA methylation sites of LeCTR1. (D) Relative expression level of LeEIN3. (E) DNA methylation rate of CpG island of LeEIN3. (F) Changes of DNA methylation sites of LeEIN3. Each line represents 1 clone, and 1 circle represents $1 \mathrm{CpG}$ site. The black circle represents the methylated CG, and the white circle represents the 
unmethylated CG. Vertical bars represent standard deviations of the means. Asterisks indicate statistical difference of the values at $\mathrm{P}<0.05\left(^{*}\right)$ or $\mathrm{P}<0.01(* *)$.

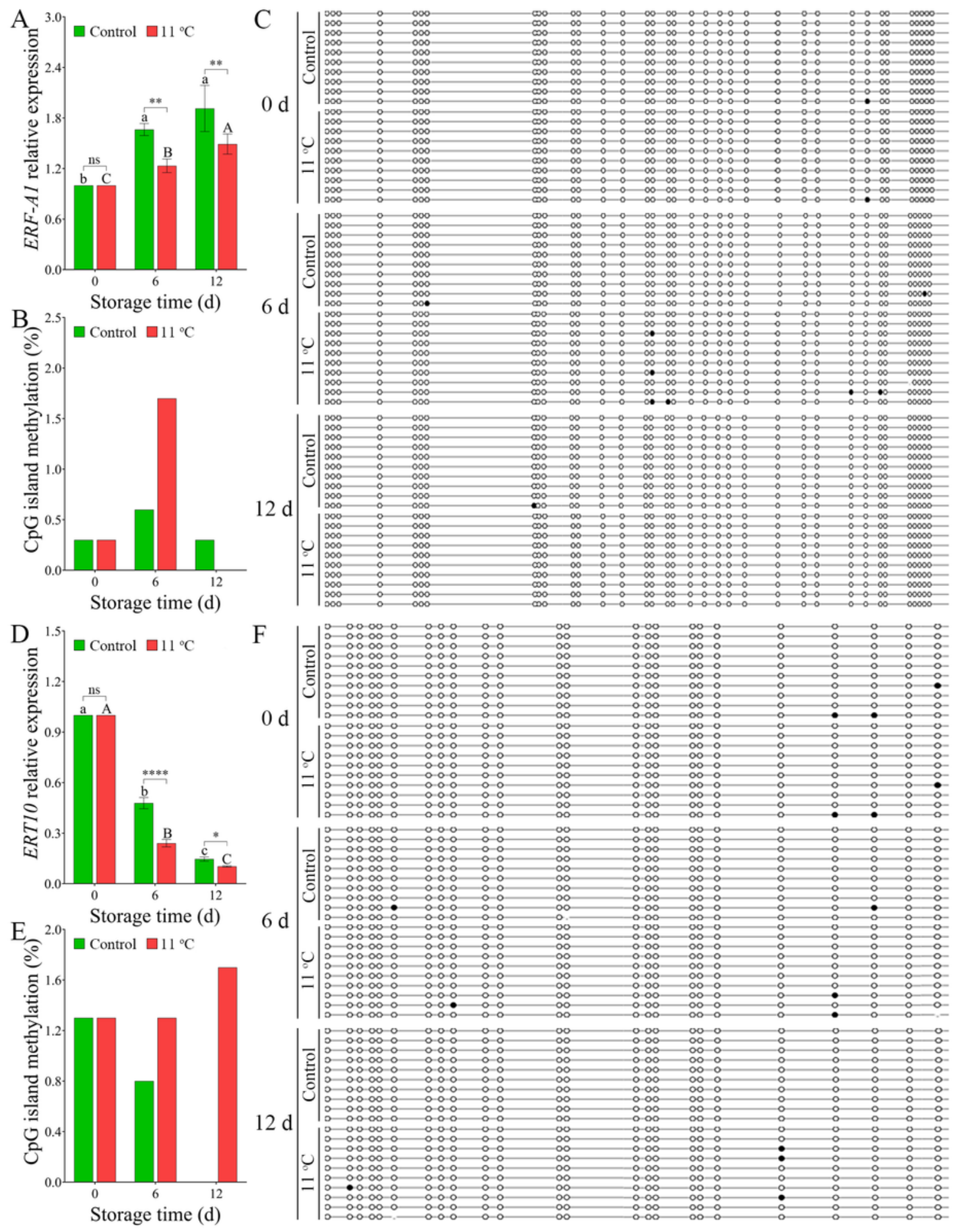

Figure 7

Expression level and DNA methylation rate of SIERF-A1 and LeERT10 in tomato fruit. (A) Relative expression level of SIERF-A1. (B) DNA methylation rate of CpG island of SIERF-A1. (C) Changes of DNA methylation sites of SIERF-A1. (D) Relative expression level of LeERT10. (E) DNA methylation rate of CpG 
island of LeERT10. (F) Changes of DNA methylation sites of LeERT10. Each line represents 1 clone, and 1 circle represents $1 \mathrm{CpG}$ site. The black circle represents the methylated CG, and the white circle represents the unmethylated CG. Vertical bars represent standard deviations of the means, $n=3$. Asterisks indicate

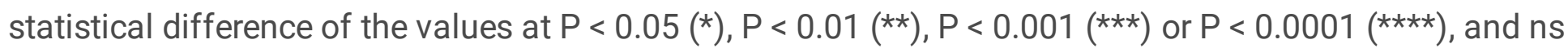
$=$ no significant.

\section{Supplementary Files}

This is a list of supplementary files associated with this preprint. Click to download.

- Supplementary.docx 